\title{
PENGARUH JUMLAH UANG BEREDAR TERHADAP INFLASI DAN SUKU BUNGA, SERTA TERHADAP INVESTASI DAN PERTUMBUHAN EKONOMI DI INDONESIA
}

\author{
Karari Budi Prasasti ${ }^{a}$ \\ Edy Juwono Slamet ${ }^{b}$ \\ ${ }^{a}$ Sekolah Pascasarjana Universitas Airlangga ${ }^{\mathrm{b}}$ Fakultas Ekonomi dan Bisnis Universitas Airlangga \\ Email: k.budiprasasti@inbox.Iv ; edyjuwonos@yahoo.com ${ }^{\mathrm{b}}$
}

ARTICLE HISTORY

Received:

9 Februari 2020

Revised

5 March 2020

Accepted:

21 March 2020

Online available:

9 Mei 2020

Keywords:

Money Supply, Inflation, Interest Rate, Investment, Economic Growth.

Kata Kunci:

Jumlah uang beredar, Inflasi,

Suku Bunga, Investasi, Pertumbuhan

Ekonomi.

\section{ABSTRACT}

Introduction: Monetary policy is one of the main instruments of macroeconomic policy. The government with monetary policy is able to influence the level of economic growth, employment, and the rate of inflation. The one of main monetary policy is controlling the money supply. Money supply has a widespread impact on other macro variables. This study analyzes the effect of the money supply to variable inflation and interest rates, as well as the effects of inflation and interest rates to investment and economic growth in Indonesia.

Methods: This study used analysis of TSLS (Two Stages Least Square). The data used in Times Series. Data for the period 1973 until 2012.

Results: From the tests showed that there was a significant effect of money supply to inflation and interest rates. Inflation and interest rates has no effect on investment in Indonesia partially. While there was the simultaneous effect of inflation and interest rates to Investment in Indonesia. The research showed that significantly the investment influence economic growth in Indonesia.

Conclusion and suggestion: Research indicates that the variable in the money supply directly or indirectly have an impact on economic growth in a country, thus appropriate monetary policy should be given such a broad impact in an economy. 


\section{ABSTRAK}

Kebijakan moneter merupakan salah satu instrumen utama dalam kebijakan ekonomi makro. Dengan menggunakan kebijakan moneter pemerintah mampu mempengaruhi tingkat pertumbuhan ekonomi, pengangguran, kesempatan kerja, dan juga tingkat inflasi. Adapun kebijakan moneter salah satunya adalah mengedalikan jumlah uang beredar. Uang beredar memiliki dampak yang meluas terhadap variabel makro lainnya. Penelitian ini menganalisis pengaruh dari jumlah uang beredar terhadap variabel inflasi dan suku bunga, serta pengaruh inflasi dan suku bunga terhadap investasi dan pertumbuhan ekonomi di Indonesia.

Pengujian menggunakan metode TSLS (Two Stages Least Square). Data yang digunakan berupa data Times Series selama periode 1973 sampai dengan 2012. Dari pengujian yang dilakukan menunjukkan bahwa terdapat pengaruh signifikan jumlah uang beredar terhadap inflasi dan suku bunga. Secara parsial inflasi dan suku bunga tidak berpengaruh terhadap investasi di Indonesia. Secara simultan inflasi dan suku bunga berpengaruh bersama-sama terhadap Investasi di Indonesia. Dari penelitian ini juga diketahui bahwa investasi berpengaruh signifikan terhadap pertumbuhan ekonomi di Indonesia. Penelitian yang dilakukan menunjukkan bahwa variabel jumlah uang beredar langsung maupun tidak langsung akan memberikan pengaruh terhadap pertumbuhan ekonomi di suatu negara, sehingga dalam mengambil suatu kebijakkan moneter haruslah tepat mengingat dampaknya yang begitu luas dalam suatu perekonomian.

\section{INTRODUCTION}

Dalam menjalankan perekonomian suatu negara, pemerintah memiliki lembaga yang bertanggung jawab sebagai stabilisator keseimbangan moneter dan pasar keuangan di Indonesia khususnya perbankan. Bank Indonesia sebagai badan yang bertanggung jawab dalam mengatur dan mengawasi sistem perbankan, memiliki peranan yang sangat besar, antara lain yaitu dengan membuat kebijakan moneter (moneter policy). Bank Indonesia merupakan institusi yang penting. Kebijakan Bank Indonesia memiliki pengaruh yang besar terhadap tingkat inflasi dalam jangka panjang serta terhadap tenaga.

Teori kuantitas uang telah menjelaskan bahwa pertumbuhan uang merupakan determinan utama dalam tingkat inflasi. Oleh karena itu pengendalian jumlah uang beredar merupakan hal yang penting untuk dilakukan oleh bank indonesia mengingat dampaknya yang luas terhadap variabel makro lainnya. Inflasi sendiri merupakan fenomena ekonomi yang kompleks. Inflasi mampu mempengaruhi stabilitas perekonomian suatu negara. Dampak dari inflasi yang tinggi diantaranya adalah 
terjadinya redistribusi pendapatan dan kekayaan diantara kelompok yang berbeda, serta penyimpangan pada harga relatif dan output barang yang berbeda. Berbagai upaya ditempuh pemerintah untuk mengendalikan laju inflasi.

Variabel lainnya yang dipengaruhi oleh jumlah uang beredar adalah suku bunga. Variabel ini tidak kalah penting bila dibandingkan dengan inflasi. Suku bunga mewakili pembayaran pada masa mendatang untuk transfer pada masa lalu. Suku bunga melibatkan perbandingan jumlah uang pada masa waktu yang berbeda (Mankiw, 2008:35). Suku bunga merupakan variabel yang banyak diamati dalam perekonomian. Bahkan setiap hari pergerakkan dari suku bunga dilaporkan oleh surat kabar. Variabel suku bunga dianggap penting karena variabel tersebut mampu mempengaruhi masyarakat dalam mengambil keputusan mengalokasikan uangnya. Suku bunga menjadi bahan pertimbangan bagi masyarakat dalam menentukkan pengalokasian dananya, apakah untuk konsumsi, ditabung, atau melakukan investasi. Perubahan-perubahan yang terjadi pada sisi moneter ini pada akhirnya memberikan dampak yang besar terhadap investasi.

Dalam upaya peningkatkan pertumbuhan ekonomi suatu negara banyak sekali faktor-faktor yang mempengaruhi. Salah satunya adalah investasi. Hal tersebut sesuai dengan empat roda pertumbuhan (Samuelson, 2001:276) diantaranya adalah sumber daya manusia, sumber daya alam, formasi modal, dan teknologi. Akan tetapi permasalahan yang muncul adalah, sebagai negara berkembang tingkat investasi di Indonesia masih sangat rendah.

Penelitian sebelumnya pernah dilakukan oleh Eny Setyowati dan Siti Fatimah NH (2007) dalam penelitiannya yang berjudul Analisis Faktor-Faktor Yang Mempengaruhi Investasi Di Dalam Negeri Di Jawa Tengah Tahun 1980-2002. Disini peneliti meneliti tentang berbagai faktor yang mempengaruhi investasi dalam negeri di Jawa Tengah dengan variabel yang diteliti antara lain; suku bunga, inflasi, PDRB, dan tenaga kerja. Disini hasil penelitian menunjukkan bahwa inflasi dannsuku bunga mempunyai pengaruh negatif terhadap investasi dalam negeri

Pada akhirnya kebijakan moneter dalam mengatur jumlah uang beredar ternyata mampu memberikan pengaruh kompleks dan luas terhadap variabel makro lainnya serta memberikan dampak yang besar dalam kondisi perekonomian suatu

negara. Sehingga kebijakan moneter haruslah benar-benar tepat agar mampu mengatasi masalah-masalah yang timbul dalam perekonomian dan dapat menstabilkan kondisi perekonomian suatu negara.

\section{LITERATURE REVIEW}

\section{The traditional society}

Hubungan antara jumlah uang beredar dengan inflasi digambarkan melalui Teori 
kuantitas. Dalam teori tersebut menjelaskan bahwa inflasi terjadi melalui dua hal yaitu jumlah uang beredar dan harapan masyarakat mengenai kenaikkan harga-harga dikemudian hari (Mankiw, 2012:79). Dalam analisis pereferensi likuiditas (liquidity preference framework) yang dikembangkan oleh Keynes, menjelaskan keseimbangan suku bunga dalam terminologi permintaan dan penawaran uang. Ketika penawaran uang meningkat (variabel lain dianggap tetap), maka akan menyebabkan tingkat bunga akan turun (Mishkin, 2008:154).

Menurut Eachern (2000 : 140) menyebutkan bahwa inflasi yang tidak diantisipasi mengakibatkan redistribusi pendapatan dan kekayaan dari suatu kelompok ke kelompok lain, sehingga mengurangi kemampuan untuk membuat rencana jangka panjang dan memaksa pembeli dan penjual untuk memperhatikan harga-harga. Semakin inflasi sulit diramalkan semakin sulit juga melakukan negosiasi jangka panjang, seperti halnya investasi. Menurut teori klasik, semakin tinggi tingkat bunga, keinginan untuk melakukan investasi semakin kecil. Hal ini disebabkan kerana seorang pengusaha/investor akan bersedia menambah pengeluaran investasinya apabila keuntungan dari investasinya lebih besar dibandingkan dengan keuntungan dari tingkat bunga apabila dia menabung di Bank.

\section{RESEARCH METHODS}

Dalam penelitian ini menggunakan teknik analsis TSLS. Dimana pengujian akan melalui beberapa tahap. Tahap pertama yaitu untuk menguji pengaruh dari jumlah uang beredar terhadap tingkat inflasi. Tahap kedua yaitu untuk menguji pengaruh dari jumlah uang beredar terhadap tingkat suku bunga. Dari dua tahap pengujian yang dilakukan akan menghasilkan variabel-variabel prediktor baik dari inflasi maupun suku bunga. Variabel inilah yang kemudian akan dipergunakan dalam pengujian tahap tiga. Pengujian tahap tiga digunakan untuk mengetahui pengaruh dari inflasi dan suku bunga prediktor terhadap tingkat investasi. Dari pengujian tahap tiga ini kemudian akan dihasilkan variabel prediktor dari investasi. Variabel ini kemudian akan dipergunakan dalam pengujian tahap empat. Pengujian tahap empat dimaksudkan untuk melihat pengaruh dari investasi prediktor terhadap pertumbuhan ekonomi.

\section{RESULT AND ANALYSIS}

Pengujian hipotesis dilakukan dengan beberapa tahap. Pengujian hipotesis satu melibatkan persamaan struktural pertama. Dimana tujuan dari pengujian hipotesis satu ini adalah untuk mengetahui pengaruh jumlah uang beredar terhadap tingkat inflasi. Hasil pengujian menggunakan eviews menunjukkan bahwa variabel jumlah uang beredar berpengaruh signifikan terhadap tingkat inflasi di Indonesia. Hal tersebut dapat diamati 
dari tingkat probabilitas sebesar 0,0256 lebih kecil dari Critical Value. Dari pengujian ini dihasilkan persamaan Y1 $=1,395+2,93 X 1+$ e. Koefisien 1,395 menunjukkan apabila keadaan variabel lain dianggap tetap maka nilai inflasi sebesar $1,395 \%$. Kenaikkan pada jumlah uang beredar sebesar $1 \%$ akan memicu kenaikkan pada inflasi sebesar 2,93\%. Sedangkan pengaruh dari jumlah uang beredar ke inflasi sebesar $60 \%$. Ini dapat dilihat dari nilai R-square sebesar 0,60.

Tabel 1

Hasil regresi jumlah uang beredar terhadap tingkat inflasi di Indonesia

\begin{tabular}{crcl}
\hline Variable & Coefficient & Std. Error & Prob. \\
\hline C & 1.395183 & 1.977757 & 0.0000 \\
Jumlah Uang Beredar & 2.931198 & 1.871641 & 0.0256 \\
R-squared & 0.600631 & & \\
\hline
\end{tabular}

Sumber: Pengolahan Eviews

Pengujian berikutnya melibatkan persamaan struktural dua. Pengujian melalui OLS ini dimaksudkan untuk mengetahu pengaruh jumlah uang beredar terhadap tingkat suku bunga. Pada uji hipotesis dua ini diperoleh hasil bahwa jumlah uang beredar memiliki pengaruh signifikan terhadap tingkat suku bunga di Indonesia. Hal tersebut dapat dilihat dari tingkat probabilitas sebesar 0,06 yang lebih kecil dari critical value. Persamaan struktural yang diperoleh dari uji ini dengan koefisien Y2 $=14,64-2,33 X 1+$ e. Hal tersebut berarti bahwa, tanpa adanya pengaruh dari jumlah uang beredar, maka tingkat suku bunga sebesar 14,64\%. Sedangkan 2,33 menjelaskan bahwa dengan mengasumsikan variabel diluar persamaan dalam kondisi tetap maka setiap perubahan pada jumlah uang beredar sebesar $1 \%$, akan menyebabkan tingkat suku bunga naik sebesar 2,33\%. Sedangkan nilai Rsquare sebesar 0,79 menunjukkan bahwa variabel jumlah uang beredar memberikan pengaruh sebesar $79 \%$ terhadap tingkat suku bunga. Sedangkan sisanya dipengaruhi variabel lain di luar model.

Tabel 2

Hasil regresi jumlah uang beredar terhadap tingkat suku bunga di Indonesia

\begin{tabular}{crrl}
\hline Variable & Coefficient & Std. Error & Prob. \\
\hline C & 14.64775 & 1.274279 & 0.0000 \\
Jumlah Uang Beredar & -2.338207 & 1.205908 & 0.0600 \\
R-squared & 0.790029 & & \\
\hline
\end{tabular}

Sumber: Pengolahan Eviews

Pengujian hipotesis tiga melibatkan persamaan struktural tiga. Dimana yang menjadi variabel eksogen dalam persamaan ini adalah variabel presiktor dari inflasi dan suku bunga yang dihasilkan dari pengujian tahap satu. Tujuan dari uji hipotesis tiga ini adalah uantuk mengetahui pengaruh dari inflasi dan suku bunga prediktor terhadap investasi di Indonesia. Dari pengujian yang dilakukan variabel prediktor dari inflasi dan suku bunga secara individu tidak memberikan pengaruh signifikan terhadap Investasi. Hal tersebut dapat diamati dari tingkat probabilitas inflasi prediktor dan suku bunga prediktor sebesar 0,2739 dan 0,7885 yang lebih dari Critical Value. Sedangkan secara bersama-sama (simultan) variabel inflasi dan suku bunga prediktor berpengaruh 
signifikan terhadap investasi. Hal tersebut dapat dilihat dari nilai probabilitas $\mathrm{F}$ sebesar 0,0006 yang lebih kecil dari Critical value $(\propto=1 \%)$.

Tabel 3

\begin{tabular}{crrr} 
Hasil regresi pengaruh inflasi dan suku bunga terhadap investasi di Indonesia \\
\hline Variable & Coefficient & Std. Error & Prob. \\
\hline C & 22372796 & 47181933 & 0.6382 \\
Inflasi & -8.387601 & 7.542351 & 0.2739 \\
Suku Bunga & -1.667388 & 6.170249 & 0.7885 \\
R-squared & 0.449626 & & \\
\hline
\end{tabular}

Sumber: Pengolahan Eviews

Pada pengujian hipotesis empat melibatkan persamaan empat, dimana pada pengujian ini yang menjadi variabel eksogen adalah variabel prediktor dari investasi yang dihasilkan dalam pengujian sebelumnya. Pengujian hipotesis empat dimaksudkan untuk mengetahui pengaruh dari investasi prediktor terhadap pertumbuhan ekonomi di Indonesia. Dari pengujian yang dilakukan dapat diketahui bahwa investasi prediktor berpengaruh signifikan terhadap pertumbuhan ekonomi. Hal tersebut ditunjukkan oleh nilai probabiltas sebesar 0,0001 yang lebih kecil dari Critical Value $(\alpha=1 \%)$. Dan membentuk persamaan Y4 $=1,76+1,07 Y 3+$ e. Dengan asumsi bahwa variabel di luar model dalam keadaan tetap, maka tanpa adanya pengaruh dari investasi prediktor nilai dari pertumbuhan ekonomi sebesar $1,76 \%$. Sedangkan perubahan $1 \%$ pada investasi akan meningkatkan pertumbuhan sebesar 1,07 satuan. Besar pengaruh dari investasi ke pertumbuhan ekonomi dapat dilahat dari nilai R-square sebesar 0,647 hal tersebut menjelaskan bahwa investasi mempengaruhi pertumbuhan ekonomi sebesar $64 \%$ sedangkan sisanya dipengaruhi variabel lain diluar model.

Tabel 3

\begin{tabular}{crcc} 
Hasil regresi investasi terhadap pertumbuhan ekonomi di Indonesia \\
\hline Variable & Coefficient & Std. Error & Prob. \\
\hline C & 1.764640 & 1.043448 & 0.0000 \\
Investasi & 1.076459 & 2.392876 & 0.0001 \\
R-squared & 0.647498 & & \\
\hline
\end{tabular}

Sumber: Pengolahan Eviews

Inflasi dan suku bunga merupakan dua variabel ekonomi yang memberikan dampak terhadap perekonomian. Tinggi atau rendahnya inflasi akan berpengaruh terhadap stabilitas perekonomian. Apabila inflasi tinggi maka akan menyebabkan ketidakpastian ekonomi. Ketidakpastian inilah yang akan memicu para investor selaku pelaku dunia usaha menjadi enggan untuk melakukan investasi. Akan tetapi hasil dari pengujian yang dilakukan inflasi menunjukkan bahwa dalam jangka pendek inflasi tidak memberikan pengaruh signifikan terhadap investasi. Hal tersebut ditunjukkan dengan nilai probabilitas yang lebih besar dari Critical value. 
Pengujian yang dilakukan menghasilkan dua kesimpulan. Pertama, inflasi dan suku bunga secara parsial tidak berpengaruh terhadap investasi, sehingga dalam jangka pendek perubahan dari inflasi dan suku bunga tidak akan mempengaruhi investasi. Hal tersebut dapat terjadi dikarenakan oleh adanya berbagai faktor yang mempengaruhi investasi diluar variabel inflasi dan suku bunga. Perubahan pada tingkat inflasi dan suku bunga dalam jangka pendek tidak sepenuhnya mampu memperngaruhi keputusan investor dalam melakukan investasi. Terdapat berbagai pertimbangan lain yang mempengaruhi keputusan investor dalam melakukan investasi diantaranya adalah infrastruktur, kestabilan politik, keamanan, dan berbagai faktor lainnya.

Kedua, penelitian ini juga menunjukkan bahwa secara simultan atau bersamasama inflasi dan suku bunga berpengaruh signifikan terhadap investasi dalam jangka panjang. Perubahan yang terjadi pada inflasi dan suku bunga dalam jangka panjang akan mempengaruhi ekspektasi investor dalam melakukan investasi. Ketidakstabilan kondisi makroekonomi akan menyebabkan investor enggan untuk malakukan investasi. Penelitian ini sesuai dengan teori yang dikemukakan oleh Eachern (2000 : 140) yang menyebutkan bahwa inflasi tinggi dan tidak diantisipasi mengakibatkan redistribusi pendapatan dan kekayaan dari suatu kelompok ke kelompok lain, sehingga mengurangi kemampuan untuk membuat rencana jangka panjang dan memaksa pembeli dan penjual untuk memperhatikan harga-harga. Semakin inflasi sulit diramalkan semakin sulit juga melakukan negosiasi jangka panjang, seperti halnya investasi.

Negara yang lebih banyak melakukan investasi akan memiliki tingkat pertumbuhan yang lebih tinggi apabila dibandingkan dengan negara yang lebih sedikit mengalokasikan PDB untuk investasi. Penelitian yang lebih lanjut menunjukkan hubungan yang kuat antara investasi dengan pertumbuhan ekonomi. Pengakumulasian modal akan memberikan pengaruh terhadap produktivitas sehingga jelas bahwa tingkat investasi yang tinggi akan mendorong pertumbuhan ekonomi yang lebih cepat.

Hasil dari penelitian ini secara otomatis mendukung teori yang dikemukakan oleh Solow (Van Den Berg, 2005:115) yang menjelaskan bahwa peningkatan pada investasi atau akumulasi modal akan mempengaruhi GDP dan pada akhirnya akan berpengaruh signifikan terhadap pertumbuhan ekonomi. Penelitian ini juga mendukung teori yang mengemukakan bahwa pertumbuhan ekonomi suatu negara disokong oleh empat roda pertumbuhan. Konsep dari pertumbuhan ekonomi tersebut menjelaskan bahwa komponen pembentuk pertumbuhan ekonomi yang didasarkan pada empat roda atau empat faktor pertumbuhan (Samuelson, 2005:250) yaitu sumber daya manusia, sumber daya alam, pembentukan modal, dan teknologi. Hal tersebut secara jelas menunjukkan bahwa pembentukkan modal merupakan komponen penting yang menunjang pertumbuhan ekonomi suatu negara. Penelitian ini juga sesuai dengan penelitian yang pernah dilakukan sebelumnya oleh Fatima (2010) dan Njogo (2012). Dimana hasil 
penelitian menunjukkan bahwa investasi berpengaruh positif dan signifikan terhadap pertumbuhan ekonomi.

\section{CONCLUSION}

Jumlah uang beredar berpengaruh positif dan signifikan terhadap tingkat inflasi di Indonesia. Jumlah uang beredar berpengaruh negatif dan signifikan terhadap tingkat suku bunga di Indonesia. Inflasi dan suku bunga secara parsial tidak berpengaruh signifikan terhadap tingkat investasi di Indonesia. Sedangkan secara simultan atau bersama-sama tingkat inflasi dan suku bunga berpengaruh signifikan terhadap investasi di Indonesia. Sedangkan Investasi berpengaruh positif dan signifikan terhadap pertumbuhan ekonomi di Indonesia.

\section{REFERENCES}

Al khatib PhD, Hazem B. 2011. Economical Determinants Of Domestic Investment. European Scientific Journal.

Arikunto, Suharsimi. 2006. Prosedur Penelitian Suatu Pendekatan Praktek. Edisi Revisi IV. Jakarta: PT. Rineka Cipta

Aryaningsih, Ny Nyoman. 2008. Pengaruh Suku bunga, Inflasi, dan Jumlah Penghasilan Terhadap Permintaan Kredit Di PT. BPD Cabang Pembantu Kediri. Jurnal penelitian dan pengembangan sains dan humaniora. (www.freewebs.com/santyasa/Lemlit/.../Ni Nyoman Aryaningsih.pdf, diakses 2 Oktober 2009)

Boediono. 2008. Ekonomi Makro. Yogyakarta : BPFE-Yogyakarta

BPS. Statistik Indonesia. Surabaya : BPS Surabaya.

Devie. 2000. Tinjauan atas Suku Bunga dan Dampaknya Pada Keputusan Investasi Dan Pembiayaan. Jurnal Ekonomi Akuntansi Fakultas Ekonomi Universitas Petra. Vol; 2, No. 2, Nopember 2000. (http://puslit.petra.ac.id/journals/accaunting, diakses 14 Maret 2014)

Fatima, Goher. 2012. Joint Impact Of Investment (Public And Private) On The Economic Growth Of Pakistan: (Co-Integration Approach). International Journal of Humanities and Social Science. Vol: 2, No. 15 Maret 2014

Hossain, A (2005). The granger-causality between money growth, inflation, currency devaluation and economic growth in indonesia: 1954-2002.

Hossain, A (2005). The sources and dynamics of inflation in Indonesia: An ECM model estimation for 1952-2002.

Indikator Makro Ekonomi. Jakarta: BPS

Johansen, S. and K. Juselius. (1990), "Maximum Likelihood Estimation and Inference on Co-integration with the Application to the Demand for Money", Oxford Bulletin of Economics and Statistics, Vol. 52, pp. 169-210. 
Jun, Zhang. 2003. Investment, Investment Efficiency, and Economic Groth in China.Journal Of Asian Economics.

Keynes, J. M. (1936) The General Theory of Employment, Interest and Money (London: Macmillan).

Khan S. and Senhadji S. (2001): "Threshold Effects in the Relationship between Inflation and Growth", IMF Staff Papers, WP. 48 No. 1, 1-21.

Lipsey, Richard G dan Peter O Steiner. 1988. Macroeconomics. New York : Harper and Row.

Luvia Albu, Lucian. 2006. Trends In The Interest Rate-Investment-GDP Growth Relationship. Romanian Journal of Economic Forecasting.

Madura, Jeff. 2006. Financial Institutions and Markets. Edisi ketujuh. China : Thomson South-Western.

Mankiw, N. Gregory. 2012. Pengantar Ekonomi. Edisi Asia. Jakarta : Salemba Empat.

Mc. Eachern dan William A. 2000. Ekonomi Makro: Pendekatan Kontemporer. Jakarta: Erlangga

Mackie, J.A.C. (1967). Problems of the Indonesian Inflation. Monograph Series. Department of Asian studies, Cornell University, Ithaca, New York.

Mishkin, Federic. S. 2010. The Economics of Money, Banking, and Financial Market. Edisi kesepuluh. United States : Pearson Education.

Ngoa Tabi, Henri. 2011. Inflation, Money, and Economic Growth in Cameroon. International Journal Of Financial Research Vol:2, No.1, Maret 2011.

Njogo. 2012. Foreign Direct Investment: Source Economic Growth in Nigeria.International Journal of Current Research, April 2012.

Nopirin. 2000. Pengantar Ekonomi Makro Dan Mikro. Yogyakarta: BPFE Yogyakarta

Nordhous dan Samuelson, 2004. Ilmu Makro Ekonomi, Jakarta: Media Global Edukasi

Phillips, A. W. (1958). "The Relationship between Unemployment and the Rate of Change of Money Wages in the United Kingdom 1861-1957".

Rosyidi, Suherman. 2000. Pengantar Ilmu Ekonomi. Jakarta: Erlangga.

Ritter, Lawrence dan William L. Silher. 1993. Principles of Money, Banking, and Financial Markets. Edisi kedelapan. United States of America:Library of Congress Cataloging in Publication Data.

Smith, John. 2003. Controversies in Moneteary Economics. Edisi revisi. United Kingdom : Library of Congress cataloguing in Publication Data.

Solow, Robert M. (1956). A Contribution to the Theory of Economic Growth. .Quarterly Journal of Economics (The MIT Press) 70 (1): 65-94.

Statistik Indonesia. Jakarta: BPS

Sugiono. 2005. Metode Penelitian Bisnis. Bandung: Alfabeta

Sukirno, Sadono. 2001. Pengantar Teori Makro Ekonomi. Jakarta : Raya Grafindo Persada.

Swan, Trevor W. (November 1956). "Economic Growth and Capital Accumulation." Economic Record (John Wiley \& Sons) 32 (2): 334-361.

Tambunan, Tulus. 2006. Perekonomian indonesia sejak orde lama hingga orde baru. Jakarta : PT. Pustaka Quantum Prima. 
Tambunan, Tulus. 2006. Iklim Investasi di Indonesia.(http://kadin-indonesia.or.id, diakses 20 April 2010)

Todaro, Michael P dan Stephen C, Smith. 2003. Economic Development. Edisi Kedelapan. London: Pearson.

Van Den Berg, Hendrik. 2005. Economic Growth and Development. New York: McGrawHill.

Wikipedia. Inflasi. (http: //id.wikipedia.org/wiki/Inflasi). 